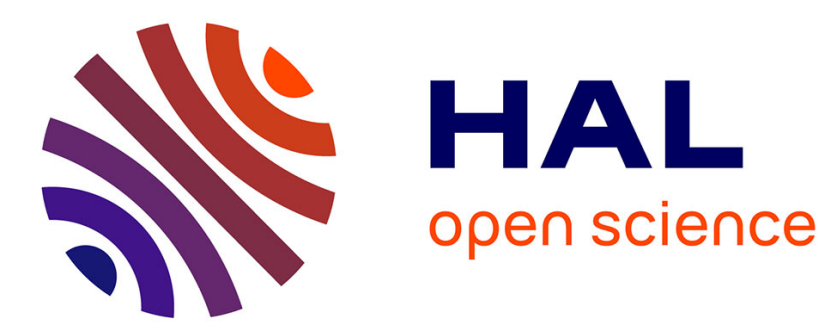

\title{
"marvellous and surprizing conduct": The "Masque of Devils" and Dramatic Genre in Thomas Shadwell's The Tempest
}

Claude Fretz

\section{- To cite this version:}

Claude Fretz. "marvellous and surprizing conduct": The "Masque of Devils" and Dramatic Genre in Thomas Shadwell's The Tempest. Restoration: Studies in English Literary Culture, 1660-1700, 2019, 43 (2), pp.3-28. 10.1353/rst.2019.0010 . hprints-03437606

\section{HAL Id: hprints-03437606}

\section{https://hal-hprints.archives-ouvertes.fr/hprints-03437606}

Submitted on 20 Nov 2021

HAL is a multi-disciplinary open access archive for the deposit and dissemination of scientific research documents, whether they are published or not. The documents may come from teaching and research institutions in France or abroad, or from public or private research centers.
L'archive ouverte pluridisciplinaire HAL, est destinée au dépôt et à la diffusion de documents scientifiques de niveau recherche, publiés ou non, émanant des établissements d'enseignement et de recherche français ou étrangers, des laboratoires publics ou privés. 


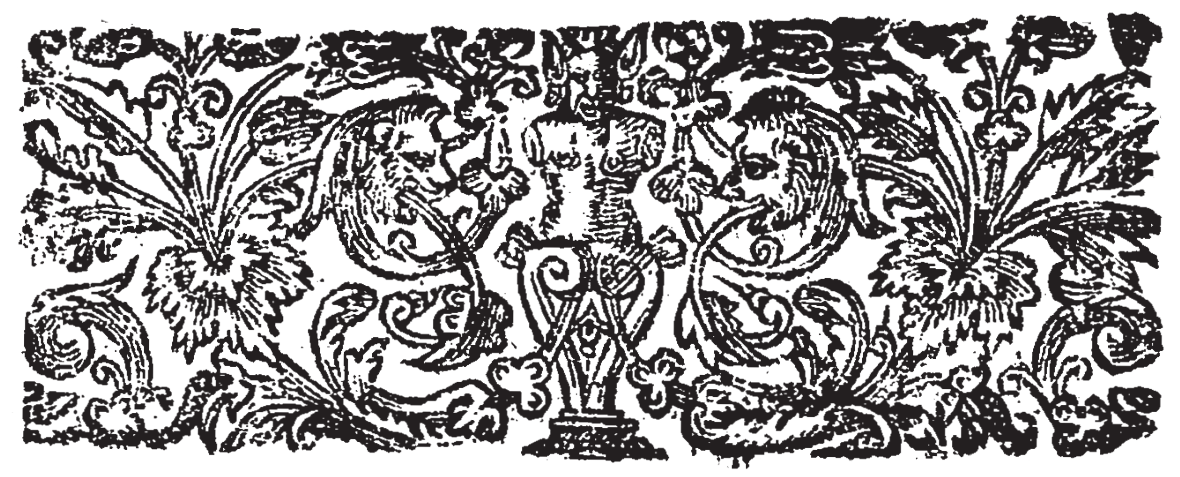

Restoration Volume 43.2

\title{
"marvellous and surprizing conduct": The "Masque of Devils" and Dramatic Genre in Thomas Shadwell's The Tempest
}

\author{
Claude Fretz
}

The epilogue to one of the most successful plays of the Restoration period, Thomas Shadwell's 1674 adaptation of Shakespeare's The Tempest (1611), entitled The Tempest, or The Enchanted Island, speaks of poets' ghosts that haunt actors in "Visions bloudier th[a]n King Richard's was" (Epilogue, 9). ${ }^{1}$ The epilogue suggests that the famous dream scene from Shakespeare's Richard III (c.1593), in which the king is haunted by visions of the ghosts of those he has murdered, would have been recognizable already to the first generation of theatergoers after the bard's own. ${ }^{2}$ This says something important about the attractiveness of staged dreams and visions at that time, not least because Shadwell's Enchanted Island is itself full of strange visions, including the "Masque of Devils" in 2.4, set to music by Pelham Humfrey and Pietro Reggio, in which Prospero's spirits appear onstage as devils and terrify Alonso, Antonio, and Gonzalo.

Even though it took the Restoration theatre companies some time to turn to The Tempest-John Dryden and William Davenant did not revise it until 1667_-Shakespeare's play is exceptionally well suited to the popular semi-operatic performance style of this period, featuring masque-like entertainment, singing, magic, and a tragicomic plot. ${ }^{3}$ I use the word "tragicomic" here mainly for want of a more appropriate critical term, because there continues to be disagreement amongst scholars over how to categorise The Tempest - as well as Pericles (1607), The Winter's Tale (1609), and Cymbeline (1610), with which it is usually grouped together. The terms "romance," "tragicomedy," "late play," and "last works" are routinely floated, but none of them are universally accepted. ${ }^{4}$ 
A similar question of genre arises with regard to Restoration drama, despite its neo-classical undercurrents: plays like William Davenant's The Law Against Lovers (1662)—a hybrid of Shakespeare's Measure for Measure (1603) and Much Ado About Nothing (1598)_-Thomas Killigrew's Pandora (1664), and John Dryden's Secret Love, or The Maiden Queen (1667) combine romantic and tragic or heroic plots. ${ }^{5}$ Most germane to the phenomenon of genre hybridization, however, are the period's so-called dramatick operas. These are a group of plays produced between 1673 and the turn of the century, including Shadwell's Enchanted Island, Henry Purcell's Fairy-Queen (1692) — an adaptation of A Midsummer Night's Dream (1595)—and Charles Gildon's Measure for Measure, or, Beauty the Best Advocate (1700). Unlike the continental operas that were entirely sung, the English dramatick operas integrated dialogue spoken by actors and interspersed with songs. Especially through their aurally and visually spectacular offering, these plays challenge dramatic precepts of verisimilitude, unity, and genre, prompting Judith Milhous to differentiate them from the Restoration's "ordinary comedies and tragedies."

Whereas most scholarly work on Restoration Shakespeare has focused on textual changes, on the plays' political contexts, or on their musical settings, this article uses the example of the "Masque of Devils" in the 1674 Enchanted Island to show how Shadwell and his collaborators hybridized dramatic genre through spectacle. Furthermore, it argues that the integration of semi-operatic spectacle and generic innovation in the "Masque of Devils" was not purely a Restoration invention, but something that Dryden, Davenant, and Shadwell—with their aesthetic nous and political awareness—-developed from Shakespeare's original Tempest. ${ }^{7}$ Rather than being a Restoration addition to the play, Shadwell's "Masque of Devils"- - like Dryden and Davenant's shorter equivalent masque in the 1667 version (published in 1670) - is in fact a subtle iteration of a moment in 3.3 of Shakespeare's play, where Ariel appears as a harpy, accompanied by thunder and lightning. ${ }^{8}$ Intriguingly, 3.3 marks one of the most generically indeterminate episodes in The Tempest, because even though it belongs to a play that the 1623 folio identifies as a comedy, it relies heavily on devices derived from tragedy. ${ }^{9}$ The present article sets out to explore how Shadwell and his collaborators used a combination of spectacle and textual as well as musical revision to expand the original play's tragic-comic dynamics. Uniquely, the article does not just draw on textual analysis, but also considers how genre hybridization manifests itself in performance. To achieve that, I take into account likely staging conditions in the Restoration playhouses, before drawing on contemporary performance-as-research as a means of deepening our understanding of the generic category of "dramatick opera" and of the Restoration-era processes of revision that culminated in Shadwell's Enchanted Island. The article's final section incorporates observations made during a practice-based workshop on Shadwell's 1674 adaptation of The Tempest that was held on 10-13 July 2017 at the Globe's Sam Wanamaker Playhouse, an indoor space based on Restorationera drawings of an unknown playhouse, possibly by John Webb. The approach taken here will redress some of the imbalance bemoaned by Pilar Cuder-Domínguez when she writes that "the focus on the [political] ends [of Restoration drama] has resulted in some neglect of the means employed." ${ }^{10}$ 
By examining the connections, rather than the textual differences, between The Tempest and The Enchanted Island, this article also challenges the misperception that the Civil War and the subsequent resumption of theatrical activity marked a somehow radical break with pre-war dramatic activity. As Moelwyn Merchant rightly notes, "[i]t is possible to exaggerate the degree of change and to forget the continuity with the age of Shakespeare which so much of this work demonstrates." ${ }^{11}$ Despite the fact that a successful Restoration production of Shakespeare usually entailed substantial rewriting-Shakespeare was viewed as raw material that needed to be refined in terms of both language and dramaturgy-Restoration theatre in many ways marks a continuation of creative developments around spectacle, musicality, and genre that had begun in the Jacobean and Caroline eras, not least because of the enduring influence of pre-war court masques like those designed by Inigo Jones. ${ }^{12}$ Furthermore, the tragicomic plays of the Restoration have antecedents in Shakespeare's late plays as well as in the tragicomic works of Fletcher and Beaumont-which were frequently adapted using similar strategies as for Shakespeare to render them more musical. The developments in stage spectacle, music, and genre seen particularly from the Jacobean period onwards also go hand in hand, because the plays' variety of spectacle was matched by increased flexibility in genre and plot. As Tiffany Stern writes, the diverse entertainments in Shakespeare's Blackfriars plays - masques, songs, stage effects - "may [...] explain why Shakespeare and Fletcher became interested in the tragicomedic form [, whose] varied style will have seemed suited to an audience with wayward or wandering attention." ${ }^{13}$ The transmission of pre-war dramatic and generic principles to the Restoration, whose indoor theatre culture and political context—namely, the "tragicomedy" of regicide and restored monarchy—made it receptive to the dramatic strategies and varied plots as found in Shakespeare's Blackfriars plays, becomes apparent from the way in which Shadwell's "Masque of Devils" adapts ideas that Shakespeare had already played with in 3.3 of his original Tempest. Using the "Masque of Devils" as its focal example, this article will show how the study of spectacle and genre allows us to trace a genealogy of Restoration stagecraft and dramatick opera that is more continuous with the early modern commercial theatre than we tend to expect.

\section{I}

What Restoration playwrights and audiences likely found attractive about masquelike and quasi-supernatural moments like Richard III's dream or the various visions and illusions in The Tempest was that they facilitated both the showcasing of special stage effects and the performance of music, song, and dance. Because of the rules of verisimilitude, it was often difficult to justify music and singing in drama; sudden singing and dancing were more often than not irreconcilable with mimesis. As Jeffrey Barnouw writes, "[m] usic was a signal that verisimilitude was being suspended." ${ }^{14}$ In order to ensure smooth transitions into multimedia entertainments, playwrights therefore had to search for ways to deploy music in moments where doing so would not seem absurd. Frequently, they turned to moments of supernatural visitation or intervention, which in the Restoration often involved flight machines. On top of hiding the noise produced by the creaking movements of the machines' ropes and wires, songs, dance, and music in such scenes were 
immune to objections on grounds of verisimilitude, because the supernatural spectacle of which they formed part already exceeded the possibilities and expectations of the natural world. Thus, Restoration playwrights increasingly incorporated such scenes not simply because the supernatural was entertaining, but also out of necessity. As Jocelyn Powell notes, "it was really only in those scenes that employed the apparatus of the supernatural that the full richness of stage effect and musical splendour could find excuse." ${ }^{15}$ In the same vein, Steven E. Plank writes that "Restoration audiences fully expected their theatre to be a musical one [...] but they required that it be, for the most part, rationally appropriate," and only "[m]agical scenes peopled by those from the irrational, supernatural world might rationally proceed in music." 16 This commonplace prevalence of music and supernatural figures was mocked in George Villiers's satire The Rehearsal (1671), aimed at Dryden, in which the character Bayes (a caricature of Dryden) tells Smith: "you must ever interlard your Plays with Songs, Ghosts and Idols." ${ }^{17}$

The supernatural visions in Shakespeare's late plays, in particular, supplied exactly what Restoration playwrights were looking for: the introduction of supernatural figures like gods, ghosts, or spirits; the suspension of natural law and verisimilitude; and, in consequence, the potential for masque-like and musical entertainment. It was following his company's move to the Blackfriars Theatre in 1608, in fact, that Shakespeare composed not only some his most musical plays, but also those in which supernatural figures are most present. As Stern has pointed out, the reasons for this lay in the need for Shakespeare to "subsume" features of the boy actors' performances at the Blackfriars- the Children of the Chapel Royal, who acted at the Blackfriars until 1608, were choristers-and in the fact that the Blackfriars precinct was popular with composers and instrumentalists. ${ }^{18}$ Stern also speculates that the Blackfriars's "smoky atmosphere [...] may have encouraged plays about ghosts, spirits and people who lost their way." ${ }^{19}$ In addition, the Blackfriars's design enabled more advanced stage devices than the outdoor theatres where Shakespeare's plays had previously been performed: as part of its construction, for example, "an enclosed platform had been built high above the stage to house the apparatus used in celestial flights." ${ }^{20}$ Working in an indoor theatre culture of their own, Restoration playwrights were keen to exploit the dramaturgical and representational strategies of Shakespeare's late works. This is illustrated by the fact that Shadwell's "Masque of Devils," which extends over sixty lines, is twice as long as Ariel's appearance as a harpy in The Tempest, which runs over just thirty lines. Shadwell and his collaborators also significantly expanded the cognate "Masque" that featured in Dryden and Davenant's initial 1667 adaptation of The Tempest (which runs over just 37 lines) by adding Reggio's "Arise, ye subterranean winds," performed by a singing devil and twelve dancing "winds" in order " $[\mathrm{m}]$ ore to disturb their [i.e. the usurpers'] guilty minds" (Enchanted Island, 2.4.132). On top of that, they expanded Dryden and Davenant's material by turning the devils' song and the non-specific allegorical representations of Pride, Fraud, Rapine, and Murder into a politically charged commentary on the Treaty of Dover (through which Charles II promised to convert to Roman Catholicism) and on Charles's wider rapprochement with his Catholic cousin Louis XIV of France - consider, for example, the addition of a reference to "barb'rous Monarchs who their Neighbours invade, / And their Crowns unjustly get" $(2.4 .67-8) .^{21}$ 
Notwithstanding Shadwell's political motives, it is likely that the more advanced stage effects in Restoration theatres were progressively making supernatural visions and theophanies more compelling than they had been in Shakespeare's time. In Elizabethan and much of Jacobean theatre, supernatural figures tended simply to walk onto the stage; as Andrew Gurr points out, Jupiter in Cymbeline was the first god in Shakespeare to descend from the skies. ${ }^{22}$ Indeed, the fact that the few heavenly entrances found in Shakespeare are all in the late plays suggests according to Stern that "only Shakespeare's last theatre, Blackfriars, had a mechanism for a descending 'heavenly' chair." ${ }^{23}$ By the time of the Restoration, in contrast, the widespread use of musical effects, flight machines, and other ground-breaking stage devices had made moments of supernatural intervention or visitation much more spectacular.

As in Shakespeare's stagecraft after 1608, where the mixture of aural and visual entertainment was accommodated by the generically, stylistically, and narratively varied tragicomedy, the intertwining of music, stage effects, and supernatural plot elements in the Restoration, too, had profound implications for dramatic genre. In the preface to Albion and Albanius (1685) - which itself was not actually a dramatick opera but was sung all the way through - Dryden argued that the impossibility of staging music and dance while adhering to the dramatic principles of mimesis and probability meant that deities and other supernatural elements could only plausibly be staged in the genre of the English dramatick opera, which he defined as a "poetical Tale or Fiction, represented by Vocal and Instrumental Musick, adorn'd with Scenes, Machines and Dancing." ${ }^{24}$ But there is a lot more to this dramatic category than musicality and spectacle, because the need for supernatural elements in order accommodate the music gave the dramatick opera a peculiar kind of plot: namely, one that frustrates expectations of verisimilitude and mimesis and instead encourages marvels and miracles that would be inconsistent with the precepts of comedy, tragedy, or tragicomedy. ${ }^{25}$

Restoration playwrights' deviations from dramatic conventions, particularly in dramatick opera, were heavily inspired by theatrical endeavours in the pre-war period. Not only do the supernatural characters on the Restoration stage derive from pre-war court masques—as Plank notes, they are the "direct progeny of the antimasquers"-but the technical ingenuity and generic hybridity (or indeterminacy) of the dramatick opera, too, have antecedents in the Jacobean and Caroline tragicomedies, romances, and masques. ${ }^{26}$ Powell puts it well when he writes that "[s]emi-opera elaborated the masque-like spectacles so often found in Jacobean and Caroline tragedy and comedy, blended them with a new variety[,] and created a strange and haunting, if thoroughly hybrid, theatrical experience. ${ }^{27}$ The lavish use of scenery, stage machinery, elaborate costumes, music, dance, and olfactory effects in the pre-war masques makes them precursors of Restoration drama; as David Lindley observes, "court shows, like Prospero's island, were full of noises, sounds, and sweet airs," and "[t] he court masque $[\ldots]$ permitted the evolution of musical and theatrical techniques that look forward to the post-Restoration era." ${ }^{28}$ Lindley's comparison of the court show with Prospero's island is a good one, because The Tempest, like Restoration drama, is strongly and directly influenced by the court masque tradition: Shakespeare in this play did not just stage a wedding masque (see 4.1.35-138) and include 
numerous supernatural figures, but also more broadly took inspiration from conventions and devices associated with the court masque. ${ }^{29}$ As Shakespeare's ultimate exploration of the possibilities of aural and visual extravagance, The Tempest supplied Restoration playwrights with abundant material which they could reuse or adapt to satisfy the aesthetic demands of their audiences and to exploit the staging possibilities presented by their indoor playhouses, including machines and movable scenery. These special effects of Restoration theatre were met with approval by avid theatregoer Samuel Pepys: when seeing Davenant's Macbeth (1667), in which the witches famously flew on and off stage with the help of flight machines using ropes and wires, he remarked on the play's excellence "especially in divertissement." ${ }^{30}$ Pepys also saw the Davenant-Dryden production of The Tempest (1667) on several occasions, and on 13 November 1667 and 3 February 1668 praised it for its "variety." ${ }^{1}$ As one of Shakespeare's tragicomic late plays, The Tempest offered its Restoration adapters not just a blueprint for "variety" of spectacle, but also for variety and flexibility of genre, providing them with narrative turns and twists that even allowed them to navigate the potentially dangerous political waters of their time.

This is not to say, of course, that little or nothing in the Restoration versions of The Tempest is original. In catering to the dramatic standards and aesthetic (as well as political) expectations of their time, Davenant and Dryden, and later Shadwell, reworked most of Shakespeare's text in order to foreground the themes of love and innocence and to defuse any threats of regicide and usurpation. They also took advantage of the possibility of casting female actors, and gave the play a greater sense of harmony and balance, by introducing new characters like Miranda's sister Dorinda, Ariel's female companion Milcha, and the young nobleman Hippolito (played by a cross-dressed actress), rightful sovereign of Mantua and deprived of his realm by Alonso. ${ }^{32}$ But at the same time, Shadwell, in particular, clearly spotted the aesthetic affinity between Shakespeare's original play and the theatrical standards of the Restoration. When he revised Dryden and Davenant's 1667 adaptation of The Tempest, he built further on the many masque-like components that had already been present in Shakespeare's text. For example, he developed the play's rich musical quality by adding even more musical (as well as visual) entertainment than Dryden and Davenant: Shadwell's first stage direction, which describes the storm conjured up by Prospero and has no equivalent in Dryden and Davenant, stipulates " 24 Violins" and "several Spirits in horrid shapes flying down amongst the Sailers, then rising and crossing in the Air" (Enchanted Island, 1.0.1,19-20). ${ }^{33}$ When it came to hybrid genre registers, too, Shadwell and his collaborators did not break radically with Shakespeare; rather, they emphasised and expanded generically ambivalent and dramatically innovative elements already present in the original Tempest. While it is true that Shadwell in 1674 (like Dryden and Davenant in 1667) adopted the First Folio's classification of Shakespeare's play as a comedy, an examination of the "Masque of Devils" and its equivalent moment in the original Tempest reveals that "comedy" is as reductive a description as any other traditional classification, because Shadwell playfully explored the tensions between comic and darker modes of experience in a similar way to how Shakespeare did in 1611. As I will show, stage spectacles, illusions, and visions are central to the generic intermixtures in both Shakespeare's and Shadwell's versions of The Tempest. 


\section{II}

In both Shakespeare's 3.3 and the Restoration "Masque of Devils," spirits or devils are seen torturing the stranded usurpers in retribution for the injustice done to Prospero. But there are notable differences, too. For example, the character of Sebastian was removed in the Restoration. There is also an intriguing difference with regard to Alonso's state of mind prior to the vision: in Shakespeare, Alonso is not penitent, but in The Enchanted Island, he is. This has profound implications for the functions and genre registers of the scenes' spectacles, as I will show.

In Shakespeare's Tempest, Alonso initially asserts that the loss of Ferdinand is the result of their visit to Tunis, where Alonso has married his daughter Claribel—a character we never meet on stage - to the Muslim king, presumably out of political considerations: "[W] ould I had never / Married my daughter there. For coming thence / My son is lost" (Tempest, 2.1.102-4). Before Ariel's intervention in the following act, there is no sign that Alonso and his lords are suffering from bites of conscience, nor do they view their political transgression as the reason for the shipwreck and Ferdinand's death. But all of that changes as a direct result of Ariel's intervention; this gives the spectacle of Ariel's appearance as a harpy a clear dramatic and narrative purpose. In 3.3, after a banquet presented to Alonso, Antonio, Sebastian, and Gonzalo vanishes by means of a "quaint device" (3.3.52.2), Ariel enters in the guise of a harpy and expressly links the characters' misfortune to the usurpation of Prospero. ${ }^{34}$ Specifically, he calls Alonso, Antonio, and Sebastian "men of sin" (53), describes himself and the other spirits as "ministers of Fate" (61), and urges the usurpers to "remember [...] that you three / From Milan did supplant good Prospero" (68-70). Later, "shapes" enter "to soft music" and taunt the three characters "with mocks and mows" (82.1-2). Ariel's adoption of the shape of a harpy in this scene nurtures the idea that quasi-divine punishment is being enacted: as $\mathrm{H}$. David Brumble explains in his dictionary of allegorical meanings, harpies "were sometimes interpreted [...] as ministers of divine punishment" and at times even "conflated with the Furies." ${ }^{35}$ As soon as Ariel's work is done, Prospero is quick to note that his "high charms work, / And these, mine enemies, are all knit up / In their distractions" (3.3.88-90). Alonso for his part comments that the vision "did bass [his] trespass" (99), thereby indicating that his guilt has been revealed or elicited through the musical and visual spectacle provided by Ariel and the shapes. These similar observations made successively by different characters underline the impact of the usurpers' vision on their consciences; despite acting in the service of the morally equivocal Prospero, Ariel in this scene successfully presents himself as a true instrument of divine justice, and is taken as such by Alonso, Antonio, and Sebastian. Gonzalo confirms the spiritual effect of Ariel's intervention on the three guilty usurpers when he reports that "[a]ll three of them are desperate" (105), adding that "[t]heir great guilt, / Like poison given to work a great time after, / Now 'gins to bite the spirits" (105-7).

Because of Shakespeare's decision to reference Alonso's voyage to Claribel's wedding and to leave the usurpers initially free from any overt pricks of conscience, a reading of Ariel as a "minister[] of Fate" (3.3.61) is plausible. Since Alonso, Antonio, and Sebastian are not just impenitent but also incorrigible-in 2.1, Antonio and Sebastian contemplate the murder of Alonso as a way of installing Sebastian as King of Naples-divine 
retribution at this point is credible. That does not mean, of course, that Ariel's actions are an extension of divine will: they remain an enactment of Prospero's will, and the magician even scripts the speech that Ariel delivers during his appearance as a harpy (see 3.3.85-6). But Ariel's actions nevertheless do fulfil a higher, moral purpose, causing the usurpers to regret or repent their past actions. In terms of dramatic effect, the usurpers' vision is akin to a tragic prick-of-conscience device. When writing The Tempest, indeed, Shakespeare was recycling many of the themes of his earlier, tragic plays, including political conspiracies, usurpations, murder plots, and the image of a tyrant or usurper haunted by the memory of his crimes. Ariel's harpy-like appearance, too, seems a device taken out of tragic plays like Richard III or Macbeth (1606): in the same way that Shakespeare visually emphasizes Richard's and Macbeth's guilt by staging the ghosts of their victims, he uses Ariel's appearance to pass moral judgement on Alonso, Antonio, and Sebastian. The retributive function of Ariel's intervention is underlined by the fact that the spirit is in this scene heard and seen only by guilty characters, and not, it seems, by the innocent Gonzalo: when Ariel first appears, only Alonso, Sebastian, and Antonio — and not Gonzalo— draw their swords (3.3.60), and Gonzalo subsequently asks Alonso why the latter stands "[i]n this strange stare" (94-5). In 3.3 of Shakespeare's play, thus, the interspersion of dramatic action with visual and musical spectacle is used to add to the play's generic intermixture and variety, infusing an ostensible comedy with darker moments of quasi-tragic tension.

Shakespeare was likely familiar with Pierre Le Loyer's A Treatise of Specters or Strange Sights (1586; translated into English by Zachary Jones in 1605), which has been identified as a possible source for Macbeth. ${ }^{36}$ In a passage which is as relevant to The Tempest as it is to Macbeth, Le Loyer writes:

Now amongst the manifold numbers of those that have their consciences troubled, by reason of their wicked and lewd lives; and are perplexed and terrified with a million of feares; we may well account those tyrants, who by vnlawfull and indirect meanes, have vsurped a tyrannicall authoritie over their owne native countries or in some strange estate; and have changed a good forme of common-wealth and governement, into an vniust and tyrannicall power [...] How often have we seene, that these men have bin troubled and tormented with most horrible phantosmes \& imaginations, which do com into their heads both sleeping $\&$ waking. ${ }^{37}$

The fact that a possible inspiration for Macbeth's fits of conscience could just as easily be a precursor for Alonso's, Antonio's, and Sebastian's fits after 3.3 demonstrates how closely parts of The Tempest resemble some of the most memorable moments of Shakespearean tragedy. It is true, of course, that nobody dies in The Tempest and that ideas of divine condemnation are less ambiguous in tragic plays like Richard III or Macbeth than they are in The Tempest, where audiences are aware that the cunning Prospero and Ariel are behind these acts of retribution. But even if the precise origins of "horrible phantosmes $\&$ imaginations" are presented very differently in The Tempest than in Richard III or Macbeth, early modern theological discourses around conscience and retribution actually 
permit the possibility of feelings of conscience emerging without direct divine (or other external) impetus. In the play's early modern context, this is important to understanding the spiritual effects of Ariel's performance on Alonso, Antonio, and Sebastian, because Ariel is not a divine instrument at all. In Shakespeare's time, awareness and memory were themselves believed to be sufficient to provoke feelings of guilt and even despair: John Donne wrote that "the art of salvation is but the art of memory," and Bishop Joseph Hall remarked that "wickedness [itself] makes men desperate." ${ }^{38}$ The reason for this was that the faculty of conscience was believed to be infused by God, meaning that God's judgement on men's actions was already internalized within the soul; as a result, no direct and explicit divine intervention was required to activate the conscience. As the theologian William Perkins explained in A Discourse of Conscience (1596), "conscience is of a diuine nature, and is a thing placed by God in the middest betweene him and man, as an arbitratour to giue sentence and to pronounce either with man or against man vnto God." ${ }^{39}$ According to early modern thought, therefore, the usurpers' vision of the harpy in Shakespeare's Tempest can plausibly provoke bites of conscience by evoking and amplifying the memory of their transgressions - even if the vision is manufactured by the not-so-divine Prospero and Ariel.

Whereas in Shakespeare's play, Alonso, Antonio, and Sebastian at times resemble tragic sinners who, trying to ignore or repress any memory of their wrongdoing, suffer from fits of conscience-like Richard III and Macbeth - the picture is completely different in Shadwell's Enchanted Island. In this adaptation (as in Dryden and Davenant's 1670 text), Alonso admits his guilt, and is repentant, from the very outset. Already in 1.1 — before the shipwreck and the loss of Ferdinand-Alonso comments on the pain that his transgressions have been causing him, telling his son:

I now am tedious to the world, and that,

By use, is so to me: But Ferdinand,

I grieve my Subjects loss in thee:

Alas, I suffer justly for my crimes

(1.1.86-9).

In The Enchanted Island, unlike in Shakespeare's Tempest, there is thus no need for any external intervention to provoke Alonso's guilty conscience. The traumatic state of denial that defined Restoration England explains why this subtle but important change was made: since Restoration playwrights had to refrain from staging any anti-royalist sentiment, the usurper Alonso's actions had to be both denounced and self-denounced from the very start, and Alonso, who in Shakespeare is the "King of Naples," furthermore had to become the "Duke of Savoy." 40

The new emphasis on Alonso's repentant state of mind in The Enchanted Island does not only alter the way audiences understand the character of Alonso, but also shapes how they view Prospero's actions. In The Enchanted Island, as in Shakespeare's Tempest, Prospero and Ariel are the architects of Alonso and Antonio's fearful vision: in 1.2, Prospero asks Ariel to "[b]e subject to no sight but mine" and instructs him to await further instructions (1.2.224-6), with the next supernatural episode being the "Masque of Devils" in 2.4. 
Intriguingly, the scene containing the "Masque of Devils" extends the emphasis on Alonso's repentance. Whereas in Shakespeare's text the voyage to Claribel's wedding in Tunis is blamed for the loss of Ferdinand, in the Restoration the Claribel excuse is removed altogether, and Alonso and Antonio readily blame the shipwreck and apparent death of Ferdinand on their past betrayals and ambitions: namely, the deposition of Prospero and the usurpation of Hippolito. In his answer to Antonio's question about how they could have averted their tragedy, Alonso laments (in both the 1674 and the 1667/1670 versions):

Then, then we should have help'd it

When thou betrai'dst thy Brother Prospero,

And Mantua’s Infant Sovereign, to my power;

And when I, too ambitious, took by force

Another's right: Then lost we Ferdinand;

Then forfeited our navy to this Tempest.

(2.4.13-18)

Antonio immediately agrees with Alonso's thinking, declaring that they "first broke Truce with Heaven" (19). This emphasis on Alonso's and Antonio's misplaced ambition harkens back to Cromwell's government during the Interregnum: the play does not only condemn Alonso and Antonio—and, by implication, the Commonwealth—politically and morally, but through the spiritual dimension added by Antonio's reply also depicts their acts as violations of God's will. The rationale behind this rewriting is consistent with the political principles governing other Restoration adaptations of Shakespeare: Richard III was presented as a tragicomic story about a failed (Commonwealth) tyrant, and Macbeth was altered partly in order to portray the protagonist's ambition even more explicitly as his main vice. ${ }^{41}$ Alonso's and Antonio's altered states of mind in The Enchanted Island, though, do not just transmit a political message that would have resonated with Restoration audiences, but fundamentally change the way the "Masque of Devils" is construed. Since it is no longer necessary to provoke fits of conscience in Alonso and Antonio, or to purge their minds, the masque has no obvious narrative or characterological function. Instead, the purpose of the masque's aural and visual spectacle revolves around the intermixing of different generic registers and forms of entertainment, as I will show.

Dryden and Davenant, and later Shadwell and his collaborators, must have been conscious that their rewritings raised questions around conscience, repentance, and retribution, because they explicitly foregrounded them. When Antonio in both the 1667/1670 and the 1674 texts attributes the shipwreck to his usurpation of his "Brother's fertile Lands" (2.4.22), Gonzalo disagrees vehemently:

These, Sirs, were crimes of a black die;

But both of you have made amends to Heav'n

By your late Voyage into Portugal;

Where, in defence of Christianity,

Your valour has repuls'd the Moors of Spain (24-8). 
Any audience will know, of course, that Gonzalo is wrong in dissociating the shipwreck from their past crimes; after all, Prospero, whom they wronged, is the architect of their shipwreck. Gonzalo's point that Alonso and Antonio's crusade has absolved their guiltin other words, that their works have merited their salvation-also smacks of Catholicism, while Alonso's retort that "[n]o act but penitence can expiate guilt" (2.4.30) repudiates it. The characters' theological disagreement—like the devils' condemnation of "barb'rous Monarchs who their Neighbours invade" in Shadwell's "Masque" (2.4.67-8)—might reflect the dramatists' efforts of capitalizing or commenting on political and religious Anglican-Catholic tensions at the time, fuelled by the supposed Catholic sympathies of Charles II. The latter had a Catholic wife, pursued a policy of greater tolerance towards Roman Catholics, and allegedly converted to Catholicism on his deathbed. Additionally, Charles's brother and heir to the throne, James, had embraced Catholicism, and all of this led to growing anti-Catholic hysteria and fears of Catholic influence at court. ${ }^{42} \mathrm{But}$ aside from these religio-political undertones, Alonso's emphasis on the need for penitence ironically underlines further the unnecessary nature of any additional punishment in the play, because the usurpers are in fact penitent and have sought grace and forgiveness even before their shipwreck (see 1.1.89), unlike in Shakespeare's text. As I will suggest, this changed portrayal of Alonso and Antonio as a result of their penitence nurtures conflicting on- and offstage understandings of the ensuing masque: the characters find it terrifying whereas audiences are aware of its true nature and moral ambiguity. By combining the study of textual alterations and Restoration playing conditions with practice-based performance research, I will show how Shadwell's "Masque" relies on a spectacle underpinned by textual and musical revision in order to create a dynamic mixture of comic and tragic registers.

The "Masque of Devils" in Shadwell's adaptation begins with an improvised flourish of music described by Gonzalo as being "in the air" (2.4.35). Gonzalo's comment that the characters "must be stranded [o]n the dominions of some merry Devil" (36) hints at the grotesque, playful, or mocking nature of the musical flourish. Meanwhile, Antonio's report of "Swift voices flying by [his] ear" (38) implies that the music's origin is unclear to them. The musical effects created elsewhere in the play lend credence to this assumption, with Ferdinand at one point wondering: "Where should this Musick be? I'th'air, or earth?" (3.1.12). It is likely that a Restoration audience could have experienced the musical effects similarly to the characters. As Mark A. Radice has explained, Dorset Garden Theatre, where Shadwell's Tempest was performed, allowed for musical effects to originate from the stage, the music room (above the proscenium arch), the balconies, the substage area, the ascending or descending flight machines, or the "pit between the parterre and the stage." This array of different or concurrent sources of music could have prevented audiences from ascertaining the precise source of musical effects, making them share in Ferdinand's confusion. In his study of the theatrical locations of sounds, backed up by experiments by psychologists and physicists, Bruce Smith has commented on how important it is for an audience to be able to clearly see the source of a sound effect if they want to identify its origin, leading him to conclude that "the disconnection of sound from vision is dislocating." ${ }^{34}$ Intriguingly, moreover, Will Tosh has written of a practice-based experiment in 
the Globe's indoor Sam Wanamaker Playhouse that revealed how, when "instrumentalists were positioned in different backstage locations typically specified in early modern stage directions," many members of the audience were unable to identify the music's source correctly. ${ }^{45}$ The reason for that, Tosh explains, lies in "[t]he resonating capability of the wooden playhouse," which "means that sound often fills the space in a non-directional way." ${ }^{46}$ Even if, as Tosh admits, it is uncertain "[w] hether this casts light on historical practice," his observation corroborates the argument that the musical effects created in these indoor theatres could have drawn audiences into the same states of uncertainty as are experienced by the characters in The Enchanted Island. ${ }^{47}$ In the Restoration, the use of stage machines and movable illusionistic scenes could have further supported such moments of confusion or enthrallment: according to Richard Flecknoe, "Scenes and Machines," which he described as "excellent helps of imagination, most grateful deceptions of sight," could "transport[] you easily without lassitude from one place to another; or rather by a kinde of delightful Magick, whilst you sit still, does bring the place to you." 48

Since the "Masque of Devils," as its name suggests, is meant to have a "devilish" origin, the initial flourishes of music in this scene come from beneath the stage. This is indicated by later stage directions, which stipulate a "flourish of Voyces under the Stage" (2.4.49.1) and require that the three devils sing "under the stage" (51.1), and by the description of the music as "horrid" (51) — which Radice argues seems to have been a "signal word" for music coming from below the stage. ${ }^{49}$ But the characters' bewildered reactions, Dorset Garden's design as commented upon by Radice, and a contemporaneous account like Thomas Brown's description of the playhouse as an "Inchanted Island, where nothing appears in Reality what it is, nor what it should be," cast doubt over whether the play's aural effects would have allowed for the source to be clearly identified. ${ }^{50}$ In terms of genre, if we take our cue from the announcement of a "comedy" on the title page of The Enchanted Island, this multi-layered and confusing aural and visual experience can seem to mirror some of the ontological uncertainty that is traditionally explored in comedy. In Roman New Comedy and in Shakespeare's comedies, the sight of confused and clueless characters is a source of laughter; here, characters frequently act according to partial or incorrect knowledge, and are fooled in the process. ${ }^{51}$ In The Enchanted Island, however, the spectacle of characters confused, deceived, and terrified-Alonso begs heaven to "deliver [him] from this dire place" (2.4.41) and Antonio declares that the "dreadful horrors" of the island have "unmann'd" him (46-7)—differs from moments like the mechanicals" comical alarm when they descry the metamorphosed Bottom in Shakespeare's A Midsummer Night's Dream..$^{52}$ Not only does the usurpers' terror in The Enchanted Island form part of their stern moral and political condemnation both in the context of the play and in the context of the 1670s, but it also adds to the wider threatening dynamics in the play, including the prospects of further usurpation and even murder. The scene's serious undertones only strengthen when the masque proper begins and three devils, alongside the allegorical figures of Pride, Fraud, Rapine, and Murder, torment Alonso, Antonio, and Gonzalo with songs about "Ambition" (52), "Proud Monarchs" (57), "Damned Princes" (58), and "barb'rous Monarchs" (67). As part of a neo-classical drive to maintain onstage harmony and synchrony, each of the three characters is here paired with one singing devil, 
thereby allowing for the three characters to be chastised collectively as well as individually. Similarly to Ariel's self-description as a "minister[] of Fate" in Shakespeare (Tempest, 3.3.61), moreover, the devils expressly portray themselves as heavenly agents, rhetorically deliberating whether "Heav'n [can] permit such crimes" (Enchanted Island, 2.4.83). The usurpers, too, conceive of the singing devils as instruments of divine justice, with Alonso linking them to "fearful vengeance" (64) and Antonio calling on "Sweet Heav'n" to "have mercy" (91). Because of this political topicality and quasi-tragic register, the "Masque of Devils," like Shakespeare's 3.3, always retains undertones that are difficult to reconcile with comedy. In both plays, visual and aural spectacle is integral to evoking ideas of punishment or vengeance.

In Shadwell's play, though, the masque's function is not confined to these quasitragic effects, because Antonio and Alonso are, of course, mistaken in thinking that the devils are somehow linked to God's judgement $(2.4 .62-5,91,112)$. When Alonso wonders whether "Heav'n in all its infinite stock of mercy [has] / No overflowings for [them]" (74-5), his question is more legitimate and significant than he thinks. Since the spirits or devils are not agents of heaven, the usurpers' previous acts of atonement and present calls for mercy are both irrelevant and ineffectual in this context. Unlike Shakespeare, Shadwell and his collaborators opted even to have the guiltless Gonzalo unequivocally tormented by a corresponding devil; this further complicates the masque's retributive function and suggests that Shadwell's hybridization of genre through multimedia spectacle is more nuanced than Shakespeare's cognate effect in 3.3 of The Tempest. Even though Alonso and Antonio are left "distract[ed]," or maddened, by their "Conscience" (127), any assumption that the "Masque of Devils" has some kinship with tragic prick-of-conscience moments - like the equivalent scene in Shakespeare's play, where spectacle is used to introduce a more tragic tone-looks problematic. Not only does the masque's quasi-tragic gravity awkwardly depend on the characters' misreading of the spirits as agents of heaven, but a practice-based performance workshop in the Globe's Sam Wanamaker Playhouse has also revealed that the scene's ostensibly serious tone is not supported by audience responses, partly because of the effects of its Restoration-era musical setting. Even though the characters' cognitive and spiritual agitation in this scene thematically differs from the light-hearted bewilderment so often found in comedy, it became clear during this workshop that, in performance, Shadwell's "Masque" actually continues to realize the play's comedic entertainment potential even as it fulfils a solemn thematic function. The experiment confirmed that Shadwell's "Masque of Devils" develops the generic diversity and variety of The Tempest's 3.3 even further, taking the comic-tragic tension between action and spectacle to new heights.

\section{III}

In a scholar-artist workshop held in the Sam Wanamaker Playhouse on 10-13 July 2017 as part of the research project "Performing Restoration Shakespeare," funded by the UK's Arts and Humanities Research Council (AHRC), three scenes from Shadwell's Enchanted Island were performed to a public audience by Globe actors, with the aim of investigating how Restoration adaptations of Shakespeare can be revived for modern 
audiences. One of the three scenes performed was the "Masque of Devils." The responses of participating actors and members of the audience produced valuable insights into the masque's generically ambiguous nature, thereby demonstrating that contemporary performance can shed new light on questions of genre and spectacle on the Restoration stage. Already in rehearsal, the roles of the devils generated a lot of laughter even as the general sentiment amongst actors was that, because of the plot's solemn and political dimensions, "the stakes were still serious overall," as one actor put it. The tension between, on the one hand, comical devils and, on the other hand, the much more serious themes of the overall plot was also felt by members of the audience. Spectators were amused particularly by the rising "subterranean winds" (2.4.131), performed in our production by the singing devils, who drive or blow Alonso, Antonio, and Gonzalo offstage. (In the Restoration this would have been done by a separate troupe of dancers.) The necessarily comical nature of the devils' acting and singing undermined any idea that they could be serious retributive agents, and their entrance through the trapdoor, which is meant to highlight their devilish status, only added further to their grotesque appearance and demeanour. In rehearsal, we had discussed with the actors whether the devils ought to be externalizations of the characters' guilt, real devils, or Prospero's spirits. As I have shown earlier, the play makes clear that they are Prospero's spirits, and any suggestion of the usurpers' suddenly surfacing guilt is here much less plausible than in Shakespeare's Tempest. In order to emphasise the devils' true nature even further, we contemplated the possibility of having Prospero observe the action in the way he does during the later "Masque of Neptune," which he conjures up while he is onstage (see Enchanted Island, 5.2.234-8). Regardless of the specific staging choices one makes, though, it became apparent that the "Masque of Devils" in performance offers an amusing and at times even ludicrous spectacle, thereby underlining the devils' playful and non-retributive function to the watching audience.

A further question explored during the workshop revolved around the silent onstage presence of Alonso, Antonio, and Gonzalo while the devils sing: in the absence of stage directions for the three characters, what exactly can or should they be doing? A second and related question concerned the audience's focus: is it on the actors (Alonso, Antonio, and Gonzalo), the singers (devils), or the musicians? It became clear from our experiments that the three characters must keep acting somehow; if we take our cue from the characters' periodic interjections, which exclusively consist of expressions of terror (2.4.62-4,73$8,89-91)$, the only acting permitted by the playtext involves gestures and body language that convey their fear and increasing despair. This only deepened the gulf between the characters' and the audience's reactions to the devils: to most members of the audience, the image of grotesque devils successfully depriving the three stranded characters of any hope of either forgiveness or salvation rendered the spectacle even more comical.

It is true, of course, that the mode of acting on this occasion may have been out of tune with what would have been envisaged in the Restoration: whereas a text can be transmitted throughout the ages unchanged, past performing styles are usually irrecoverable, not least because performances entail a significant amount of improvisation. Importantly, though, it was the energy and cheerfulness of Pelham Humfrey and Pietro Reggio's original musical setting that defined the acting in this scene; and the music itself contributed 
significantly to the performance's comic character. One of the participating scholars, the musicologist Sarah Ledwidge, commented:

How [...] can Humfrey's "Masque of Devils," with its frequent
excursions into major tonality and generally gleeful character, be
presented as frightening today? The posing of the question, in fact,
probably helped to unlock Shadwell's original intention, since it was
concluded that while the appearance of the devils is frightening to the
onstage villains, it is a source of amusement for the audience and for
the devils themselves.

Ledwidge's suspicion was echoed in a subsequent audience survey, with one spectator telling us that the music temporarily took away the "dark tone" of the story. Thanks to a combination of theater history, musicology, dramatic criticism, and creative practice, it became increasingly clear that the "Masque of Devils" originally must have been imagined as a moment that was neither tragic nor comic, but a dynamic conflation of the two. At the same time that the performance and the musical setting rendered the devils' intervention farcical and inhibited any sense of earnest retribution, the playtext stipulated that the characters themselves continued to believe that a higher form of punishment was being enacted. In terms of genre, therefore, there were contrasting experiences of the "Masque of Devils" in the Sam Wanamaker Playhouse: a tragic and spiritual one for the actors playing Alonso, Antonio, and Gonzalo; and a comically entertaining one for the watching audience, the singers (devils), and the musicians. Importantly, the comic facet of this scene was given full expression only when the "Masque" was performed against the backdrop of its original musical setting, as it arose from both the acting and the accompanying music. This creative tension between music and drama also points to the potential of this scene, and of the play as a whole, to offer generically disparate experiences depending on whether it is read, performed against its original musical backdrop, or staged with an adapted musical setting.

Ultimately, modern audience responses to the "Masque of Devils" make the Restoration-era textual and musical revisions appear even more important and far-reaching, because the conflicting interpretations of the devils that the play encourages amongst characters and audiences are supported by, and are dependent on, the musical setting and the textual changes made around the characterizations of Alonso and Antonio. By rendering the spiritual and condemnatory function of the masque both redundant and problematic, Davenant, Dryden, and Shadwell's textual changes enable a less serious conception of the devils and thereby fuel the scene's dramatic irony and comic-tragic register in performance. Thus, as our practice-based experiment revealed, the combined effect of textual alteration, musical performance, and acting in the "Masque of Devils" is to provoke light-hearted audience reactions to a quasi-tragic plot element. The resulting generic hybridity, in turn, helps obfuscate the moral purpose of Prospero's and Ariel's actions and-importantly in the politically febrile context of the 1670s-defuses any tragic gravity. Since these dramatic effects of spectacle on genre, and of playtext on spectacle, arise from seventeenth-century textual changes, dramaturgical strategies, and visual as well as 
aural entertainment devices, it makes sense that they can be understood more deeply, and reconstructed more fully, through a combination of textual study, attention to historical playing conditions (including material and political), and practice-based performance research.

In his examination of Restoration adaptations of Shakespeare's plays, Moelwyn Merchant arrives at the conclusion that "one of the problems throughout any consideration of these Restoration versions [is] that rarely did the literary competence of the adapters match their pretensions in handling the original text." ${ }^{4} 4$ This kind of observation has, for a long time, stained our modern view of these Restoration plays. As my comparison of Shakespeare's Tempest with Shadwell's Enchanted Island has shown, however, there are compelling reasons for considering these adaptations as serious literary and dramatic projects. The Restoration adapters of Shakespeare's Tempest were astute enough to develop and expand The Tempest's generically indeterminate moments of spectacle, and to weave them into their own semi-operatic and multimedia spectacles. In all of this, though, the influence of Shakespeare must constantly be borne in mind. As the case of The Tempest suggests, Shakespeare did not just provide stories that later dramatists could adapt, but also helped bequeath to them, especially via his Blackfriars plays, Jacobean and Caroline models of dramatic spectacle and generic innovation originally derived from court masques. While Shakespeare's ghost probably did not literally haunt Restoration actors and playwrights in "Visions bloudier th[a]n King Richard's was" (Enchanted Island, Epilogue, 9), his continuing ghostly presence was integral to the successful resumption of theatrical activity after almost twenty years of civil war.

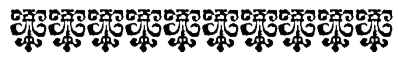

\section{Notes}

${ }^{1}$ Unless otherwise stated, all references to The Enchanted Island are to Thomas Shadwell, William Davenant, and John Dryden, The Tempest, or the Enchanted Island: A Comedy [1674], in Five Restoration Adaptations of Shakespeare, ed. Christopher Spencer (Urbana, IL: University of Illinois Press, 1965). Robert Etheridge Moore calls the 1674 Enchanted Island "the most popular play of the Restoration." Robert Etheridge Moore, Henry Purcell and the Restoration Theatre (Westport, CN: Greenwood Press, 1974), 178.

${ }^{2}$ See William Shakespeare, Richard III, ed. John Jowett (Oxford: Oxford University Press, 2008), 5.4.96-155.

${ }^{3}$ For the play's affinity with the court masque, see David Lindley, ed., The Court Masque (Manchester: Manchester University Press, 1984). For the play's incorporation of music and sound, see Michael Neill, "Noises, / Sounds, and sweet airs': The Burden of Shakespeare's Tempest," Shakespeare Quarterly 59, no. 1 (2008): 36-59. 
${ }^{4}$ On the challenges of categorizing these plays, and on the various problems with the terms "romance," "tragicomedy," or "late play," see Gordon McMullan, Shakespeare and the Idea of Late Writing: Authorship in the Proximity of Death (Cambridge: Cambridge University Press, 2007), 66-78; Barbara A. Mowat, "What's in a Name?' Tragicomedy, Romance, or Late Comedy," in A Companion to Shakespeare's Works, ed. Richard Dutton and Jean E. Howard, vol. 4 (Oxford: Blackwell, 2003), 129-49; Stanley Wells, "Shakespeare and Romance," in Shakespeare's Later Comedies: An Anthology of Modern Criticism, ed. D. J. Palmer (Harmondsworth: Penguin, 1971), 117; and Diana T. Childress, "Are Shakespeare's Late Plays Really Romances?," in Shakespeare's Late Plays: Essays in Honour of Charles Crow, ed. Richard C. Tobias and Paul G. Zolbrod (Athens, OH: Ohio University Press, 1974), 44-55.

${ }^{5}$ On the hybridization of genre in Restoration drama, see Juan A. Prieto-Pablos, "The Making of Restoration Comedy: Critical Theory and Dramatic Practice," in Genre in English Literature, 1650-1700: Translations in Drama and Fiction, ed. Pilar CuderDomínguez (Amherst, NY: Cambria Press, 2014), 72-5. On the reception of Shakespeare in the light of the late-seventeenth-century interest in classical literature, see David Hopkins, "The English Homer': Shakespeare, Longinus and English Neo-Classicism," in Shakespeare and the Classics, ed. Charles Martindale and A. B. Taylor (Cambridge: Cambridge University Press, 2004), 261-76. On the observance — and non-observanceof neo-classical protocols in Restoration drama, also see Prieto-Pablos, "Making of Restoration Comedy," 64-70.

${ }^{6}$ Judith Milhous, "The Multimedia Spectacular on the Restoration Stage," in British Theatre and Other Arts, 1660-1800, ed. Shirley Strum Kenny (Washington, D.C.: Folger Books, 1984), 61. For definitions, descriptions, and examples of dramatick opera, also see Robert D. Hume, "The Politics of Opera in Late Seventeenth-Century London," Cambridge Opera Journal 10, no. 1 (1998): 15-43; Richard Luckett, "Exotick but Rational Entertainments: The English Dramatick Operas," in English Drama: Forms and Development, ed. Marie Axton and Raymond Williams (Cambridge: Cambridge University Press, 1977), 123-41; Andrew Walkling, English Dramatick Opera, 1661-1706 (New York: Routledge, 2019); and Amanda Eubanks Winkler, "The Intermedial Dramaturgy of Dramatick Opera: Understanding Genre through Performance," Restoration: Studies in English Literary Culture, 1660-1700 42, no. 2 (2018): 13-38.

${ }^{7}$ Examples of the critical focus on textual adaptation include W. Moelwyn Merchant, "Shakespeare Made Fit," in Restoration Theatre, ed. John Russell Brown and Bernard Harris, Stratford-upon-Avon Studies 6 (London: Edward Arnold, 1965), 195-219; Sandra Clark, ed., Shakespeare Made Fit. Restoration Adaptations of Shakespeare (London: Everyman, 1997); Kristine Johanson, ed., Shakespeare Adaptations from the Restoration: Five Plays (Madison, NJ: Fairleigh Dickinson University Press, 2005); and Barbara A. Murray, Restoration Shakespeare: Viewing the Voice (Madison, NJ: Fairleigh Dickinson University Press, 2001). For a discussion of Restoration Shakespeare in its cultural and 
political contexts, see Michael Dobson, The Making of the National Poet: Shakespeare, Adaptation and Authorship, 1660-1769 (Oxford: Clarendon, 1994), chapters one and two; Gary Taylor, Reinventing Shakespeare: A Cultural History from the Restoration to the Present (New York: Weidenfeld and Nicolson, 1989), chapter one; and Nancy Klein Maguire, "Factionary Politics: John Crowne's Henry VI," in Culture and Society in the Stuart Restoration, ed. Gerald MacLean (Cambridge: Cambridge University Press, 1995), 70-92. On the politics of Restoration adaptations of The Tempest, see Katharine Eisaman Maus, "Arcadia Lost: Politics and Revision in the Restoration Tempest," Renaissance Drama 13 (1982): 189-209; Matthew H. Wikander, “The Duke My Father's Wrack': The Innocence of the Restoration Tempest," Shakespeare Studies 43 (1991): 91-8; Eckhard Auberlen, "The Tempest and the Concerns of the Restoration Court: A Study of The Enchanted Island and the Operatic Tempest," Restoration Studies in English Literary Culture, 1660-1700 15, no. 2 (1991): 71-88. For studies of music in Restoration adaptations of Shakespeare, see Kathryn Lowerre, Music and Musicians on the London Stage, 1695-1705 (Farnham: Ashgate, 2009); and Curtis Price, Music in the Restoration Theatre (Ann Arbor, MI: UMI Research Press, 1979).

${ }^{8}$ For the "Masque of Devils" in Davenant and Dryden's 1667 adaptation, see John Dryden and William Davenant, The Tempest, or, The Enchanted Island: A Comedy (London, 1670), 15-16.

${ }^{9}$ All references to The Tempest are to William Shakespeare, The Tempest, ed. David Lindley (Cambridge: Cambridge University Press, 2007).

${ }^{10}$ Pilar Cuder-Domínguez, "Introduction," in Genre in English Literature, 1650 1700: Translations in Drama and Fiction, ed. Pilar Cuder-Domínguez (Amherst, NY: Cambria Press, 2014), xi.

${ }^{11}$ Moelwyn Merchant, "Shakespeare Made Fit," 219.

${ }^{12}$ The poet and playwright Richard Flecknoe wrote that "Shakespear excelled in a natural Vein, Fletcher in Wit, and Io[]nson in Gravity and ponderousness of Style." See Richard Flecknoe, "A Short Discourse of the English Stage," in Love's Kingdom (London, 1664), G6r. This idea is also expressed in Dryden's prologue to The Enchanted Island, included in both the 1667 and the 1674 text: "As when a Tree's cut down, the secret Root / Lives under ground, and thence new branches shoot; / So, from old Shakespeare' honour'd dust, this day / Springs up and buds a new reviving Play" (lines 1-4).

${ }^{13}$ Tiffany Stern, "A ruinous monastery': The Second Blackfriars Playhouse as a Place of Nostalgia," in Moving Shakespeare Indoors: Performance and Repertoire in the Jacobean Playhouse, ed. Andrew Gurr and Farah Karim-Cooper (Cambridge: Cambridge University Press, 2014), 113. 
${ }^{14}$ Jeffrey Barnouw, "Britain and European Literature and Thought," in The Cambridge History of English Literature, 1660-1780, ed. John Richetti (Cambridge: Cambridge University Press, 2005), 434.

${ }^{15}$ Jocelyn Powell, Restoration Theatre Production (London: Routledge \& Kegan Paul, 1984), 54.

${ }^{16}$ Steven E. Plank, "'And Now About the Cauldron Sing': Music and the Supernatural on the Restoration Stage," Early Music 18, no. 3 (1990): 395-6.

${ }^{17}$ George Villiers, Duke of Buckingham, The Rehearsal (London, 1672), 23.

${ }^{18}$ Stern, "Ruinous Monastery," 106-7.

${ }^{19}$ Stern, "Ruinous Monastery," 108.

${ }^{20}$ Irwin Smith, Shakespeare's Blackfriars Playhouse: Its History and its Design (New York: New York University Press, 1964), 167. For an overview of some of the spectacle in Shakespeare's plays, including costumes, trap doors, and winches used for the descent of supernatural figures, see Evelyn Tribble, "Sight and Spectacle," in Shakespeare's Theatres and the Effects of Performance, ed. Farah Karim-Cooper and Tiffany Stern (London: Bloomsbury Arden Shakespeare, 2013), 237-52.

${ }^{21}$ Also see Murray, Restoration Shakespeare, 92.

${ }^{22}$ Andrew Gurr, The Shakespearean Stage, 1574-1642 (Cambridge: Cambridge University Press, 1992), 190.

${ }^{23}$ Tiffany Stern, “This wide and universal theatre': The Theatre as Prop in Shakespeare's Metadrama," in Shakespeare's Theatres and the Effects of Performance, ed. Karim-Cooper and Stern, 19.

${ }^{24}$ John Dryden, "Preface," Albion and Albanius (London, 1685), np. For a similar definition, see the composer Matthew Locke's preface to The English Opera, or, the Vocal Musick in Psyche (London, 1675). Psyche was a collaboration between Locke, Shadwell, and Giovanni Battista Draghi.

${ }^{25}$ Giovanni Battista Guarini, the Italian progenitor of tragicomedy, argued in Il Compendio della Poesia Tragicomica (1601) that tragicomedy should have a "verisimilar plot" and should "take from [comedy and tragedy] the parts that with most verisimilitude can stand together." Allan H. Gilbert, ed., Literary Criticism: Plato to Dryden (Detroit, MI: Wayne State University Press, 1962), 511,507. 
${ }^{26}$ Plank, "Music and the Supernatural," 394.

${ }^{27}$ Powell, Restoration Theatre Production, 24.

${ }^{28}$ David Lindley, "Introduction," in The Court Masque, ed. Lindley, 10,13. For the influence of the pre-war masques on Restoration theatre, see Dawn Lewcock, Sir William Davenant, the Court Masque, and the English Seventeenth-Century Scenic Stage, c.1605-c.1700 (Amherst, NY: Cambria Press, 2008).

${ }^{29}$ See David Lindley's introduction to Shakespeare, The Tempest, 13-18.

${ }^{30}$ Robert Latham and William Matthews, eds, The Diary of Samuel Pepys: A New and Complete Transcription, 11 vols (Berkeley, CA: University of California Press, 1971), 6:124-5.

${ }^{31}$ Latham and Matthews, eds, Diary of Samuel Pepys, 8:527, 9:48.

${ }^{32}$ For an overview of the textual changes made by the Restoration adapters, see Murray, Restoration Shakespeare, 74-88,90-5.

${ }^{33}$ Shadwell's changes also made the play more commercially attractive. John Downes, the long-serving prompter for the Duke's Company and, later, the United Company, wrote that "all things [were] perform'd in it so admirably well, that not any succeeding Opera got more money." See John Downes, Roscius Anglicanus, or an Historical Review of the Stage (London, 1708), 35.

${ }^{34}$ The "quaint device," which was likely some kind of revolving table, is an example of the visual technologies that were available to Shakespeare in the indoor Blackfriars Theatre.

${ }^{35} \mathrm{H}$. David Brumble, Classical Myths and Legends in the Middle Ages and Renaissance: A Dictionary of Allegorical Meanings (London: Fitzroy Dearborn, 1998), 148.

${ }^{36}$ Stuart Gillespie, Shakespeare's Books: A Dictionary of Shakespeare's Sources (London: Athlone Press, 2001), 278; Kenneth Muir, The Sources of Shakespeare's Plays (London and New York: Routledge, 1977), 216.

${ }^{37}$ Pierre Le Loyer, A Treatise of Specters or Strange Sights, trans. Zachary Jones (London, 1605), $112 \mathrm{r}$.

${ }^{38}$ John Donne, The Sermons of John Donne, ed. George R. Potter and Evelyn M. Simpson, 10 vols (Berkeley, CA: University of California Press, 1953-62), 2:78; Joseph Hall, The Works, 12 vols (Oxford: D. A. Talboys, 1837), 1:18. 
${ }^{39}$ William Perkins, A Discourse of Conscience (Cambridge, 1596), 5. Also see Charles B. Schmidt, Quentin Skinner, and Eckhardt Kessler, eds, The Cambridge History of Renaissance Philosophy (Cambridge: Cambridge University Press, 1988), 484.

${ }^{40}$ For the play's politics, also see Maus, "Arcadia Lost," 189-209; Wikander, "Innocence of the Restoration Tempest," 91-8; and Eckhard Auberlen, "The Tempest and the Concerns of the Restoration Court," 71-88.

${ }^{41}$ On the performance of Richard III in the 1660s, see Dobson, Making of the National Poet, 26-7. For Macbeth, see Murray, Restoration Shakespeare, 50-63.

${ }^{42}$ For seventeenth-century critiques of Charles's Catholic sympathies, see Rachel Weil, "Sometimes a Scepter is Only a Scepter: Pornography and Politics in Restoration England," in The Invention of Pornography: Obscenity and the Origins of Modernity, 1500-1800, ed. Lynn Hunt (New York: Zone Books, 1996), 125-56.

${ }^{43}$ Mark A. Radice, "Sites for Music in Purcell's Dorset Garden Theatre," The Musical Quarterly 81, no. 3 (1997): 444-5.

${ }^{44}$ Bruce R. Smith, "Within, Without, Withinwards: The Circulation of Sound in Shakespeare's Theatre," in Shakespeare's Theatres and the Effects of Performance, ed. KarimCooper and Stern, 180.

45 Will Tosh, Playing Indoors: Staging Early Modern Drama in the Sam Wanamaker Playhouse (London: Bloomsbury Arden Shakespeare, 2018), 179-80. Also see Bruce Smith's study of the theatrical locations of sound in Shakespeare's plays: Smith, "Circulation of Sound in Shakespeare's Theatre," 171-94.

${ }^{46}$ Tosh, Playing Indoors, 180.

${ }^{47}$ Tosh, Playing Indoors, 180.

${ }^{48}$ Flecknoe, "Short Discourse," G8r.

${ }^{49}$ Radice, "Sites for Music," 443.

50 Thomas Brown, Amusements Serious and Comical, Calculated for the Meridian of London (London, 1700), 48.

${ }^{51}$ For the emphasis on error and partial understanding in classical and Shakespearean comedy, see Colin Burrow, Shakespeare and Classical Antiquity (Oxford: Oxford University Press, 2013), 152-6. 
52 See William Shakespeare, A Midsummer Night's Dream, ed. Peter Holland (Oxford: Oxford University Press, 2008), 3.1.97-113.

53 Sarah Ledwidge, "Participant's Testimonial," https:/www.qub.ac.uk/schools/ ael/Research/Arts/ResearchImpact/PerformingRestorationShakespeare/Events/ TheTempestworkshopParticipantsTestimonials/ (accessed 18 January 2019).

${ }^{54}$ Moelwyn Merchant, "Shakespeare Made Fit," 218.

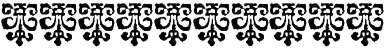

\section{Works Cited}

Auberlen, Eckhard. "The Tempest and the Concerns of the Restoration Court: A Study of The Enchanted Island and the Operatic Tempest." Restoration: Studies in English Literary Culture, 1660-1700 15, no. 2 (1991): 71-88.

Barnouw, Jeffrey. "Britain and European Literature and Thought." In The Cambridge History of English Literature, 1660-1780, edited by John Richetti, 423-44. Cambridge: Cambridge University Press, 2005.

Brown, Thomas. Amusements Serious and Comical, Calculated for the Meridian of London. London, 1700.

Brumble, H. David. Classical Myths and Legends in the Middle Ages and Renaissance: A Dictionary of Allegorical Meanings. London: Fitzroy Dearborn, 1998.

Burrow, Colin. Shakespeare and Classical Antiquity. Oxford: Oxford University Press, 2013.

Childress, Diana T. "Are Shakespeare's Late Plays Really Romances?” In Shakespeare's Late Plays: Essays in Honour of Charles Crow, edited by Richard C. Tobias and Paul G. Zolbrod, 44-55. Athens, OH: Ohio University Press, 1974.

Clark, Sandra, ed. Shakespeare Made Fit: Restoration Adaptations of Shakespeare. London: Everyman, 1997.

Cuder-Domínguez, Pilar. "Introduction." In Genre in English Literature, 1650-1700: Translations in Drama and Fiction, edited by Pilar Cuder-Domínguez, ix-xvii. Amherst, NY: Cambria Press, 2014. 
Dobson, Michael. The Making of the National Poet: Shakespeare, Adaptation and Authorship, 1660-1769. Oxford: Clarendon, 1994.

Donne John. The Sermons of John Donne. Edited by George R. Potter and Evelyn M. Simpson. 10 vols. Berkeley, CA: University of California Press, 1953-62.

Downes, John. Roscius Anglicanus, or an Historical Review of the Stage. London, 1708.

Dryden, John, and William Davenant. The Tempest, or, The Enchanted Island: A Comedy. London, 1670.

Dryden, John. "Preface." In Albion and Albanius. London, 1685.

Eubanks Winkler, Amanda. "The Intermedial Dramaturgy of Dramatick Opera: Understanding Genre through Performance." Restoration: Studies in English Literary Culture, 1660-1700 42, no. 2 (2018): 13-38.

Flecknoe, Richard. "A Short Discourse of the English Stage." In Love's Kingdom. London, 1664.

Gilbert, Allan H., ed. Literary Criticism: Plato to Dryden. Detroit, MI: Wayne State University Press, 1962.

Gillespie, Stuart. Shakespeare's Books: A Dictionary of Shakespeare's Sources. London: Athlone Press, 2001.

Gurr, Andrew. The Shakespearean Stage, 1574-1642. Cambridge: Cambridge University Press, 1992.

Hall, Joseph. The Works. 12 vols. Oxford: D. A. Talboys, 1837.

Hopkins, David. “The English Homer': Shakespeare, Longinus and English NeoClassicism." In Shakespeare and the Classics, edited by Charles Martindale and A. B. Taylor, 261-76. Cambridge: Cambridge University Press, 2004.

Hume, Robert D. "The Politics of Opera in Late Seventeenth-Century London." Cambridge Opera Journal 10, no. 1 (1998): 15-43.

Johanson, Kristine, ed. Shakespeare Adaptations from the Restoration: Five Plays. Madison, NJ: Fairleigh Dickinson University Press, 2005.

Latham, Robert, and William Matthews, eds. The Diary of Samuel Pepys: A New and Complete Transcription. 11 vols. Berkeley, CA: University of California Press, 1971. 
Le Loyer, Pierre. A Treatise of Specters or Strange Sights. Translated by Zachary Jones. London, 1605.

Ledwidge, Sarah. "Participant's Testimonial." https://www.qub.ac.uk/schools/ael/ Research/Arts/ResearchImpact/PerformingRestorationShakespeare/Events/ TheTempestworkshopParticipantsTestimonials/ (Accessed 18 January 2019).

Lewcock, Dawn. Sir William Davenant, the Court Masque, and the English SeventeenthCentury Scenic Stage, c.1605-c.1700. Amherst, NY: Cambria Press, 2008.

Lindley, David, ed. The Court Masque. Manchester: Manchester University Press, 1984.

Locke, Matthew. The English Opera, or, the Vocal Musick in Psyche. London, 1675.

Lowerre, Kathryn. Music and Musicians on the London Stage, 1695-1705. Farnham: Ashgate, 2009.

Luckett, Richard. "Exotick but Rational Entertainments: The English Dramatick Operas." In English Drama: Forms and Development, edited by Marie Axton and Raymond Williams, 123-41. Cambridge: Cambridge University Press, 1977.

Maguire, Nancy Klein. "Factionary Politics: John Crowne's Henry VI." In Culture and Society in the Stuart Restoration, edited by Gerald MacLean, 70-92. Cambridge: Cambridge University Press, 1995.

Maus, Katharine Eisaman. "Arcadia Lost: Politics and Revision in the Restoration Tempest." Renaissance Drama 13 (1982): 189-209.

McMullan, Gordon. Shakespeare and the Idea of Late Writing: Authorship in the Proximity of Death. Cambridge: Cambridge University Press, 2007.

Merchant, W. Moelwyn. "Shakespeare Made Fit." In Restoration Theatre, edited by John Russell Brown and Bernard Harris, Stratford-upon-Avon Studies 6, 195-219. London: Edward Arnold, 1965.

Milhous, Judith. "The Multimedia Spectacular on the Restoration Stage." In British Theatre and Other Arts, 1660-1800, edited by Shirley Strum Kenny, 41-66. Washington, D.C.: Folger Books, 1984.

Moore, Robert Etheridge. Henry Purcell and the Restoration Theatre. Westport, CN: Greenwood Press, 1974. 
Mowat, Barbara A. “'What's in a Name?' Tragicomedy, Romance, or Late Comedy." In $A$ Companion to Shakespeare's Works, edited by Richard Dutton and Jean E. Howard, 4 vols, 4:129-49. Oxford: Blackwell, 2003.

Muir, Kenneth. The Sources of Shakespeare's Plays. London and New York: Routledge, 1977.

Murray, Barbara A. Restoration Shakespeare: Viewing the Voice. Madison, NJ: Fairleigh Dickinson University Press, 2001.

Neill, Michael. "Noises, / Sounds, and sweet airs': The Burden of Shakespeare's Tempest." Shakespeare Quarterly 59, no. 1 (2008): 36-59.

Perkins, William. A Discourse of Conscience. Cambridge, 1596.

Plank, Steven E. "'And Now About the Cauldron Sing': Music and the Supernatural on the Restoration Stage." Early Music 18, no. 3 (1990): 392-407.

Powell, Jocelyn. Restoration Theatre Production. London: Routledge \& Kegan Paul, 1984.

Price, Curtis. Music in the Restoration Theatre. Ann Arbor, MI: UMI Research Press, 1979.

Prieto-Pablos, Juan A. "The Making of Restoration Comedy: Critical Theory and Dramatic Practice." In Genre in English Literature, 1650-1700: Translations in Drama and Fiction, edited by Pilar Cuder-Domínguez, 59-99. Amherst, NY: Cambria Press, 2014.

Radice, Mark A. "Sites for Music in Purcell's Dorset Garden Theatre." The Musical Quarterly 81, no. 3 (1997): 430-48.

Schmidt, Charles B., Quentin Skinner, and Eckhardt Kessler, eds. The Cambridge History of Renaissance Philosophy. Cambridge: Cambridge University Press, 1988.

Shadwell, Thomas, William Davenant, and John Dryden. The Tempest, or the Enchanted Island: A Comedy [1674]. In Five Restoration Adaptations of Shakespeare, edited by Christopher Spencer. Urbana, IL: University of Illinois Press, 1965.

Shakespeare, William. A Midsummer Night's Dream. Edited by Peter Holland. Oxford: Oxford University Press, 2008.

---. Richard III. Edited by John Jowett. Oxford: Oxford University Press, 2008.

---. The Tempest. Edited by David Lindley. Cambridge: Cambridge University Press, 2007. 
Smith, Bruce R. "Within, Without, Withinwards: The Circulation of Sound in Shakespeare's Theatre." In Shakespeare's Theatres and the Effects of Performance, edited by Farah Karim-Cooper and Tiffany Stern, 171-94. London: Bloomsbury Arden Shakespeare, 2013.

Smith, Irwin. Shakespeare's Blackfriars Playhouse: Its History and its Design. New York: New York University Press, 1964.

Stern, Tiffany. "AA ruinous monastery': The Second Blackfriars Playhouse as a Place of Nostalgia." In Moving Shakespeare Indoors: Performance and Repertoire in the Jacobean Playhouse, edited by Andrew Gurr and Farah Karim-Cooper, 97-114. Cambridge: Cambridge University Press, 2014.

---. "'This wide and universal theatre': The Theatre as Prop in Shakespeare's Metadrama." In Shakespeare's Theatres and the Effects of Performance, edited by Farah Karim-Cooper and Tiffany Stern, 11-32. London: Bloomsbury Arden Shakespeare, 2013.

Taylor, Gary. Reinventing Shakespeare: A Cultural History from the Restoration to the Present. New York: Weidenfeld and Nicolson, 1989.

Tosh, Will. Playing Indoors: Staging Early Modern Drama in the Sam Wanamaker Playhouse. London: Bloomsbury Arden Shakespeare, 2018.

Tribble, Evelyn. "Sight and Spectacle." In Shakespeare's Theatres and the Effects of Performance, edited by Farah Karim-Cooper and Tiffany Stern, 237-52. London: Bloomsbury Arden Shakespeare, 2013.

Villiers, George, Duke of Buckingham. The Rehearsal. London, 1672.

Walkling, Andrew. English Dramatick Opera, 1661-1706. New York: Routledge, 2019.

Weil, Rachel. "Sometimes a Scepter is Only a Scepter: Pornography and Politics in Restoration England." In The Invention of Pornography: Obscenity and the Origins of Modernity, 1500-1800, edited by Lynn Hunt, 125-56. New York: Zone Books, 1996.

Wells, Stanley. "Shakespeare and Romance." In Shakespeare's Later Comedies: An Anthology of Modern Criticism, edited by D. J. Palmer, 117-42. Harmondsworth: Penguin, 1971.

Wikander, Matthew H. “'The Duke My Father's Wrack' The Innocence of the Restoration Tempest." Shakespeare Studies 43 (1991): 91-8. 